\title{
Instability of the southern Canadian Shield during the late Proterozoic
}

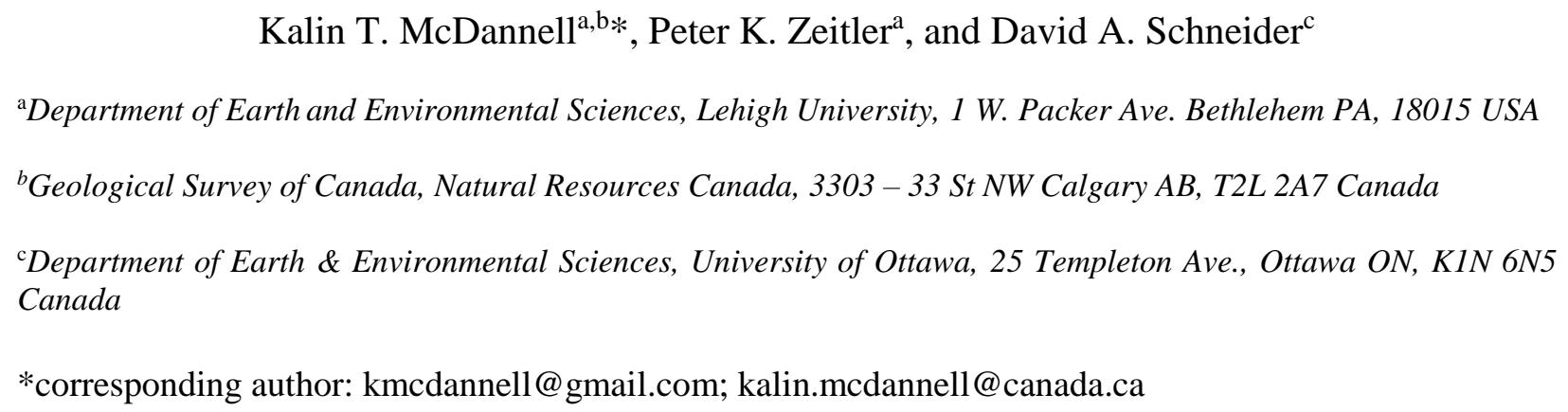

\section{ABSTRACT}

Cratons are generally considered to comprise lithosphere that has remained tectonically quiescent for billions of years. Direct evidence for stability is mainly founded in the Phanerozoic sedimentary record and low-temperature thermochronology, but for extensive parts of Canada, earlier stability has been inferred due to the lack of an extensive rock record in both time and space. We used ${ }^{40} \mathrm{Ar} /{ }^{39} \mathrm{Ar}$ multi-diffusion domain (MDD) analysis of K-feldspar to constrain cratonic thermal histories across an intermediate $\left(\sim 150-350^{\circ} \mathrm{C}\right)$ temperature range in an attempt to link published high-temperature geochronology that resolves the timing of orogenesis and metamorphism with lower-temperature data suited for upper-crustal burial and unroofing histories. This work is focused on understanding the transition from Archean-Paleoproterozoic crustal growth to later intervals of stability, and how uninterrupted that record is throughout Earth's Proterozoic "Middle Age.” Intermediate-temperature thermal histories of cratonic rocks at well-constrained localities within the southern Canadian Shield of North America challenge the stability worldview because our data indicate that these rocks were at elevated temperatures in the Proterozoic. Feldspars from granitic rocks collected at the surface cooled at rates of $<0.5^{\circ} \mathrm{C} / \mathrm{Ma}$ subsequent to orogenesis, seemingly characteristic of cratonic lithosphere, but modeled thermal histories suggest that at ca. 1.1-1.0 Ga these rocks were still near $\sim 200^{\circ} \mathrm{C}-$ signaling either reheating, or prolonged residence at mid-crustal depths assuming a normal cratonic geothermal gradient. After $1.0 \mathrm{Ga}$, the regions we sampled then underwent further cooling such that they were at or near the surface $\left(\ll<0^{\circ} \mathrm{C}\right)$ in the early Paleozoic. Explaining mid-crustal residence at $1.0 \mathrm{Ga}$ is challenging. A widespread, prolonged reheating history via burial is not supported by stratigraphic information, however assuming a purely monotonic cooling history requires at the very least $5 \mathrm{~km}$ of exhumation beginning at ca. $1.0 \mathrm{Ga}$. A possible 
explanation may be found in evidence of magmatic underplating that thickened the crust, driving uplift and erosion. The timing of this underplating coincides with Mid-Continent extension, Grenville orogenesis, and assembly of the supercontinent Rodinia. ${ }^{40} \mathrm{Ar} /{ }^{39} \mathrm{Ar}$ MDD data demonstrate that this technique can be successfully applied to older rocks and fill in a large observational gap. These data also raise questions about the evolution of cratons during the Proterozoic and the nature of cratonic stability across deep time.

\section{Introduction}

\subsection{Cratons and stabilization}

Cratons are made of ancient, tectonically quiescent continental lithosphere that has characteristically thick, chemically depleted mantle and low heat flow (e.g. Jaupart et al., 2014; Jordan, 1978; Rudnick and Nyblade, 1999). Cratons are intrinsically interesting because they record the secular evolution of the continents and a cyclic response to mantle dynamics. Moreover, cratonization and weathering of large, stable landmasses are considered integral to geo-biological evolution linked to fundamental environmental changes such as atmospheric and oceanic oxygenation and nitrification (e.g. Young, 2013 and references therein).

Here we define "stability" as resistance to internal deformation, limited magmatism, and maintenance of continental freeboard (Pollack, 1986). The established view is that most cratons underwent a period of long-term stability for most of the Proterozoic following early consolidation and exhumation at the end of the Archean. The lack of a record of significant tectonic events in the long interval between initial Archean cratonization and epeirogenic activity in the Phanerozoic is the basis for this assessment. This large time gap corresponds to the Great Unconformity, which in some places represents over 1-2 billion years of time (e.g. Karlstrom and Timmons, 2012). For the majority of the interval, time-temperature data are lacking, and

64 there are few preserved extensive or temporally continuous sedimentary rocks in many cratonic

65 terranes from this period, thus leaving the erosional record poorly constrained. Geochronologic 66 study of cratons has usually been focused either on understanding cratonization and metamorphism during orogenic suturing using high-closure temperature $\left(>500^{\circ} \mathrm{C}\right)$ methods (e.g. 
68 Schneider et al., 2007) or alternatively, examination of more recent shallow exhumation and

69 burial histories using methods with low closure temperatures ( $\left.<100^{\circ} \mathrm{C}\right)$ (e.g. Ault et al. 2009).

70 From a thermochronological standpoint, the 1 to 2 billion-year gap in the Proterozoic record

71 could simply reflect the lack of studies using methods that address the $500^{\circ} \mathrm{C}$ to $100^{\circ} \mathrm{C}$

72 temperature window.

74 This period of apparent cratonic lithosphere stability between 1.7 to $0.75 \mathrm{Ga}$ contributes to the 75 idea that it represents the "Boring Billion" or "Earth's Middle Age" (Cawood and Hawkesworth, 762014 and references therein), a time of geological, biologic, and environmental stability that is 77 attributed in part to secular cooling of the mantle and the development of a strong continental 78 lithosphere. The Columbia supercontinent cycle from ca. 2.1-1.3 Ga (Rogers and Santosh, 2002) 79 began this period of pervasive stability and endured until protracted breakup of Rodinia between ca. 0.86-0.57 Ga (Li et al., 2008). The 1.1 Ga orogenic belts that occur on several modern

81 continents (Hoffman, 1988; Li et al. 2008) are the basis for primary reconstructions of the late 82 Mesoproterozoic supercontinent Rodinia. Rodinia formed through global contractional 83 orogenesis from ca. 1.3-1.0 Ga. Reconstructed paleogeography demonstrates that the entire 84 southeastern margin of Laurentia experienced several stages of accretion between ca. 1.75 and $851.0 \mathrm{Ga}$, whereas the Laurentian core underwent continental-scale northeast-southwest extension, causing rifting and numerous dike swarms (e.g. Whitmeyer and Karlstrom, 2007).

\subsection{Stability: record or lack thereof?}

89 The Phanerozoic sedimentary record within continental interiors primarily establishes the direct

90 geologic evidence for more recent stability. Cratons in particular seem to have experienced no 91 more than $\sim 1-3 \mathrm{~km}$ of vertical motion over many hundreds of millions of years during Paleozoic-

92 Mesozoic time, based on a modest amount of stratigraphic data and low-temperature 93 thermochronology (Ault et al., 2009; Flowers et al., 2012; Flowers et al., 2006a). Suggested 94 mechanisms for the observed epeirogenic motions in North America include far-field 95 lithospheric responses to subduction (Mitrovica et al., 1989) and dynamic topography induced by 96 mantle flow (Forte et al., 2010). In central Canada, the case for stability is based mostly on what 97 is missing: a paucity of Proterozoic orogenic activity and preserved sediments, and a lack of 98 disturbed (i.e. thermally reset) geochronological systems. 
100 Extensive work in the western Superior Province suggests that orogenic activity over the

101 Kenoran interval (Kenorland; ca. 2.75 to $2.65 \mathrm{Ga}$ ) ceased by $2.6 \mathrm{Ga}$ and transitioned shortly 102 thereafter to stable cratonic lithosphere by $2.5 \mathrm{Ga}$, with some immediate post-orogenic 103 sedimentation (e.g. the Huronian Supergroup; Percival et al., 2012). Internal deformation 104 occurred during mantle plume activity in the form of the Matatchewan large igneous province 105 (LIP) and dike swarm at ca. 2.48-2.45 Ga during proto-continental breakup (Ernst and Bleeker, 106 2010) and $2.2 \mathrm{Ga}$ emplacement of the Nipissing Sills fed by the Ungava plume. The 107 Kapuskasing Uplift in the western Superior Province caused local deformation that exposed the 108 middle-lower crust at ca. 1.9 Ga (Percival and West, 1994). The 1.86 Ga Penokean Orogeny 109 resulted in the Himalayan-scale orogen that existed along the southern Superior margin, 110 synchronous with the Trans-Hudson Orogeny (THO; ca. 1.9-1.8 Ga) to the north and northwest 111 (Bickford et al., 2005) leading to Laurentian assembly. Yavapai orogenesis occured to the south 112 at ca. $1.75 \mathrm{Ga}$, leading to deposition of the Athabasca and Baraboo sequences, and other mature 113 sandstones across Laurentia (Davidson, 2008 for review). Later, Rodinia assembly and 114 Grenvillian orogenesis caused continental-scale extension, while concurrent hotspot magmatism 115 produced the 1.27 Ga Mackenzie dike swarm, 1.24 Ga Sudbury dike swarm, and the 1.1 Ga Mid116 Continental Rift (MCR) volcanism and Abitibi dike swarm (Ernst and Bleeker, 2010). Following 117 these events, subtle epeirogenic motions of up to $\pm 1-2 \mathrm{~km}$ characterized the Phanerozoic 118 (Feinstein et al., 2009; Flowers et al., 2012).

120 The Trans-Hudson Orogen underwent an orogenic and stabilization sequence analogous to that 121 of the earlier Kenoran Orogeny, where ca. 1.9 to $1.8 \mathrm{Ga}$ granulite-facies metamorphic rocks 122 (Alexandre et al., 2009; Flowers et al., 2008; Schneider et al., 2007; Williams and Hanmer, 123 2006) underlie Athabasca sediments deposited between ca. 1.7 to 1.6 Ga (Rainbird et al., 2007). 124 This was seemingly followed by quiescence until modest Phanerozoic epeirogenesis (Ault et al., 125 2009; Flowers et al., 2012). Almost a billion years of thermal record is unaccounted for after 126 initial stabilization. It is clear that certain locations on the North American craton such as 127 Athabasca show that orogenic mid-crustal rocks were exhumed into the shallow crust soon after 128 orogenesis (e.g. Williams and Hanmer, 2006). However, many other parts of the Canadian Shield 
129 are lacking conclusive information on post-orogenic activity in the late Archean through 130 Proterozoic.

132 This paper addresses the apparent post-orogenic stability of the southern Canadian Shield during 133 the Proterozoic using K-feldspar ${ }^{40} \mathrm{Ar} /{ }^{39} \mathrm{Ar}$ thermochronology and examines potential 134 mechanisms to explain the thermal histories suggested by these data, including cratonic 135 disruption near the end of the Proterozoic caused by crustal thickening and uplift due to 136 magmatic underplating. Our conclusions suggest that parts of the Canadian Shield experienced significant exhumation beginning at ca. $1.0 \mathrm{Ga}$.

\section{K-feldspar multi-diffusion domain ${ }^{40} \mathrm{Ar} /{ }^{39} \mathrm{Ar}$ thermochronology}

\subsection{Linking high and low-temperature thermochronometers}

141 Potassium feldspar is a useful mineral for ${ }^{40} \mathrm{Ar} /{ }^{39} \mathrm{Ar}$ dating because of its high $\mathrm{K}$ content,

142 ubiquity in felsic rocks, and stability during in vacuo heating (McDougall and Harrison, 1999).

143 K-feldspar is moderately retentive of radiogenic ${ }^{40} \mathrm{Ar}$, and low-temperature ordered K-feldspars

144 usually exhibit complex microstructures that lead to what has been termed multi-diffusion-

145 domain (MDD) behavior, which means that most grains of K-feldspar contain a distribution of 146 diffusion domains that can record a range of temperatures (Lovera et al., 1989; Lovera et al., 147 1991). ${ }^{40} \mathrm{Ar} /{ }^{39} \mathrm{Ar} \mathrm{K}$-feldspar MDD analysis is able to determine continuous temperature-time (T148 t) paths over the range $\sim 150^{\circ} \mathrm{C}$ to $350^{\circ} \mathrm{C}$ and the shape of age spectra can distinguish between 149 slow and rapid cooling. Continuous T-t paths can be established over this interval because the $150{ }^{39}$ Ar released during step-heating can be used to independently determine the sample's specific 151 diffusion kinetics and domain-size distribution. These data can then be used to invert the 152 observed ${ }^{40} \mathrm{Ar} /{ }^{39} \mathrm{Ar}$ age spectrum for the only remaining unknown, the thermal history. Modeling 153 for thermal history is best done using an inverse approach to eliminate observer bias from 154 forward modeling, and also speed up the recovery of a robust suite of thermal histories. K155 feldspar ${ }^{40} \mathrm{Ar} /{ }^{39} \mathrm{Ar}$ thermochronology fills the middle-temperature range between higher 156 temperature methods recording crystallization, such as U-Pb geochronology, and the low157 temperature chronometers (apatite fission-track and (U-Th)/He) that record near-surface 158 processes. 
Within a Superior Province reference frame, our craton-interior samples are spatially bracketed by well-known histories in the northwestern craton (Athabasca) and the southeastern craton margin (Grenville; fig. 1). Samples of granitic rocks from surface exposures and near-surface drill cores were chosen for their K-feldspar content and because most of the sample sites have existing high- and low-temperature thermochronologic constraints. The supplementary material contains comprehensive information on rock samples and geochronologic context.

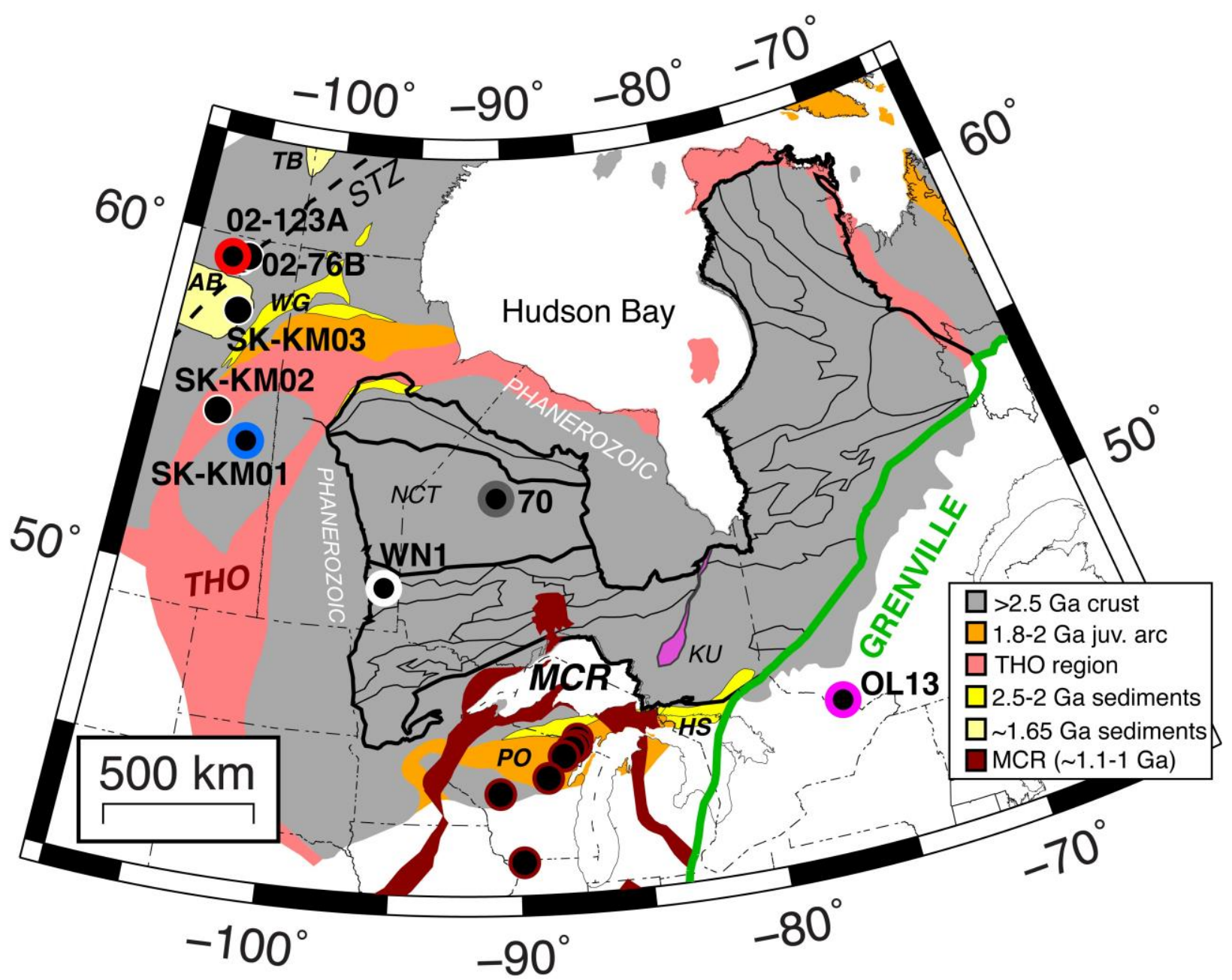

Figure 1. Map of the southern Canadian Shield modified from Whitmeyer and Karlstrom (2007) with the Superior Province (outlined by thick black line) and associated sub-terrane boundaries after Percival et al. (2006); actual western Superior craton boundary extends to the THO beneath Phanerozoic sedimentary cover. Red, blue, and violet circles correspond to samples and age spectra/thermal histories in figure 3, whereas other black dots show locations of additional K-feldspar samples we have dated by ${ }^{40} \mathrm{Ar} /{ }^{39} \mathrm{Ar}$ MDD step-heating (i.e. samples and data south of the MCR are shown in the supplement). Gray areas are $>2.5 \mathrm{Ga}$ Archean crust and orange regions are 2.0-1.8 Ga juvenile arcs of the Penokean orogen in the affected by the Trans-Hudson orogeny (THO). Darker yellow areas are 2.5-2.0 Ga post-orogenic passive 
margin sediments, $\mathrm{HS}=$ Huronian Supergroup; $\mathrm{WG}=$ Wollaston Group; $\mathrm{OG}=$ Opswagan Group . Light yellow areas are ca. 1.6-1.7 Ga sediments of the Athabasca Basin (AB) and the Thelon Basin (TB). NCT $=$ North Caribou Terrane; STZ $=$ Snowbird Tectonic Zone; THO = Trans Hudson Orogen; $\mathrm{PO}=$ Penokean Orogen; MCR = Mid-Continent Rift (dark red shading), KU = Kapuskasing Uplift (shaded violet). Green line is Grenville Province boundary.

\section{$2.2{ }^{40} \mathrm{Ar} /{ }^{39} \mathrm{Ar}$ MDD thermochronology results}

183 Granitic rocks from various parts of the Canadian Shield including the Western Superior 184 Province (Ontario) and terranes affected by the THO (Saskatchewan) yield discordant ${ }^{40} \mathrm{Ar} /{ }^{39} \mathrm{Ar}$ age spectra that systematically droop in a "staircase" manner. In a good number of cases (fig. 2) these age spectra are interpretable as reflecting diffusional response to slow cooling or reheating, unafflicted by such phenomena as breakage of large domains or late recrystallization. Overall our results align with the $\sim 70 \%$ success rate reported by Lovera et al. (2002) for a large database of samples. Information about ${ }^{40} \mathrm{Ar} /{ }^{39} \mathrm{Ar}$ dating methodology and modeling can be found in the supplementary material.
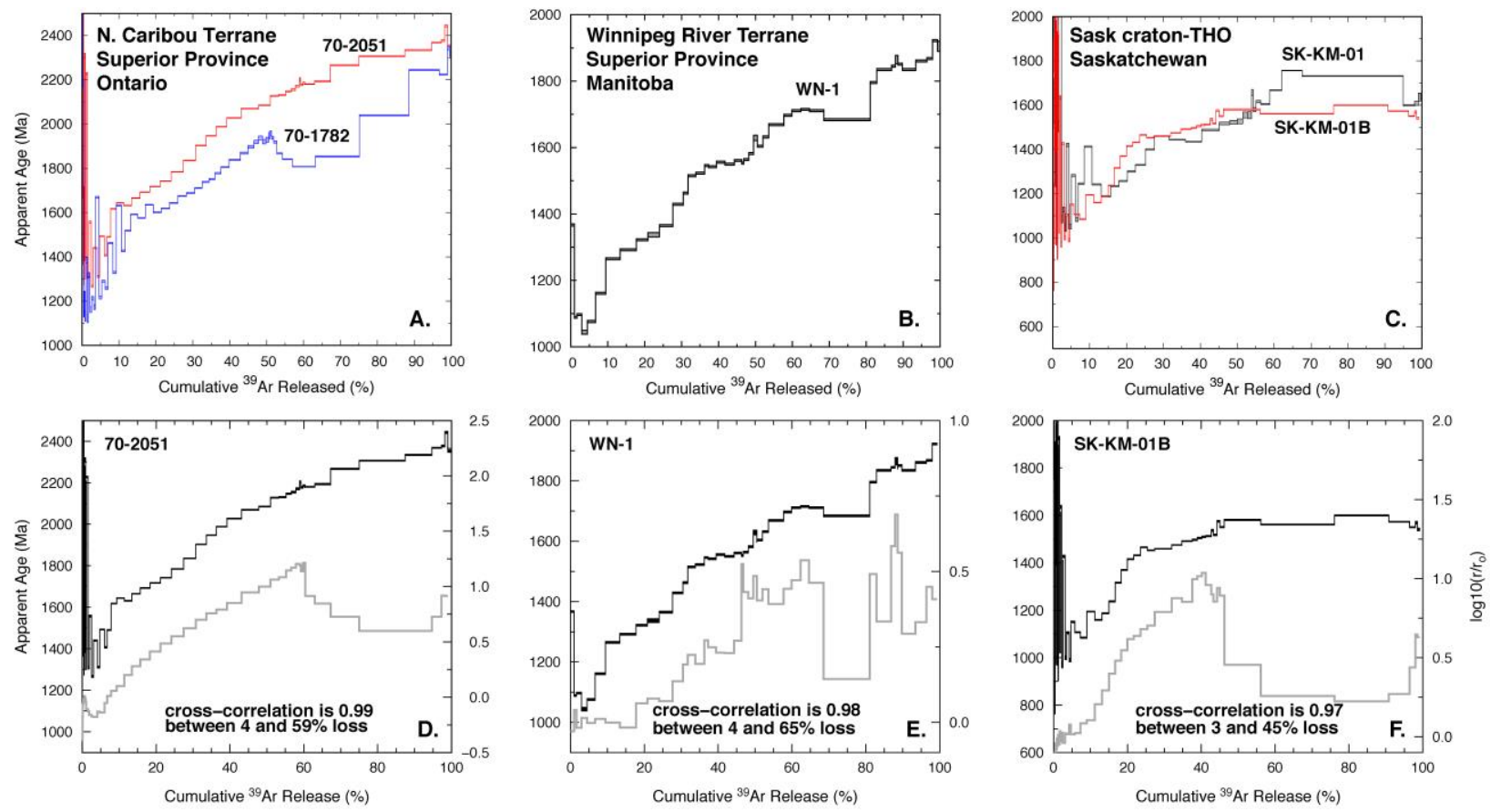

Figure 2. (A-C) Subset of step-heated ${ }^{40} \mathrm{Ar} /{ }^{39} \mathrm{Ar}$ age spectra for K-feldspars from the Canadian Shield. Superior Province samples \#70 and WN-1 illustrate slow cooling over ca. 800-900 m.y. The Sask craton sample SK-KM-01 replicates indicate slow cooling synchronous with Superior Province samples from ca. 1.6 to ca. $1.0 \mathrm{Ga}$. Most samples have excess Ar in early release steps and experienced melting near 1050$1100^{\circ} \mathrm{C}$ during heating experiments, typically at $50-70 \%{ }^{39} \mathrm{Ar}$ loss. Note that under very slow cooling conditions, different age spectra can be produced from the same sample due to subtle differences in 
diffusion domain structure, e.g. sample \#70. Sample WN-1 data from C. Roddick, pers. comm., all other age spectra are shown in supplement. (D-F) Age spectra and $\log \left(\mathrm{r} / \mathrm{r}_{\mathrm{o}}\right)$ plots (second y-axis); note the large change in right $y$-axis scale between plots. The shape of the $\log \left(r / r_{o}\right)$ plot is a function of domain size distribution (relative sizes and volumes) and represents the change in retentivity as domains are progressively outgassed. Cross-correlations between the age and $\log \left(\mathrm{r} / \mathrm{r}_{\mathrm{o}}\right)$ data show the high degree of similarity between age and laboratory diffusion spectra, after methods of Lovera et al. (2002). Under monotonic cooling conditions, a high degree of correlation (i.e. >0.90) is expected between ${ }^{40} \mathrm{Ar} /{ }^{39} \mathrm{Ar}$ age spectra and the laboratory-derived Arrhenius relationship.

Age spectra from the North Caribou Terrane (NCT) at the center of the western Superior craton (sample \#70) exhibit ${ }^{39} \mathrm{Ar}$ release patterns that span from $>2$ Ga to approximately $1.1 \mathrm{Ga}$, whereas to the southwest, in Manitoba, a Superior Province sample (WN-1) shows Ar release from ca. $1.7 \mathrm{Ga}$ to nearly $1.0 \mathrm{Ga}$. THO rocks in central Saskatchewan yield age spectra spanning the entire Mesoproterozoic. A sample from the Grenville Province in the Central Metasedimentary Belt (CMB) of Quebec (OL13) yields an age spectrum indicative of initial rapid cooling with slower post-orogenic cooling through the Cambrian. Age spectra from the northern Athabasca Basin margin denote very rapid cooling at ca. $1.7 \mathrm{Ga}$ (fig. 3A; cf. Flowers et al. 2006a,b) and other ${ }^{40} \mathrm{Ar} /{ }^{39} \mathrm{Ar}$ data from the southern Athabasca basin basement are also in agreement. Despite the small number of samples relative to the spatial distribution, the most striking observation from these data is the consistent and geographically extensive slow cooling signal recorded across the southern craton. Age gradients are large, collectively spanning the majority of the Proterozoic, amounting to ca. 500-600 million years or up to ca. 800-900 million years of cooling in the Superior Province. These gradients are generally consistent with timeintegrated slow cooling on the order of $<0.5^{\circ} \mathrm{C} / \mathrm{Ma}$ for cratonic rocks during the Proterozoic (an alternative interpretation, involving mild reheating is also possible; see below).

\subsection{Thermal history data and modeling}

In determining sample-specific kinetic information and the related diffusion-domain information, we used the ranges in K-feldspar kinetics (i.e. diffusivity and activation energies) reported by Lovera et al. (1997) as a cross-check to rule out any unreasonable values. Along with the observed age spectra and their uncertainties, these sample-specific parameters served as the primary input for our thermal history inversions. We performed thermal history modeling only on samples that obey K-feldspar MDD theory, i.e. age spectra consistent with slowly-cooled feldspars should systematically increase in age from 0 to $100 \%$ cumulative ${ }^{39} \mathrm{Ar}$ release, or 
233 alternatively, individual steps should remain consistent or equal in age during stepwise-degassing

234 of ${ }^{39} \mathrm{Ar}$ (discounting low- or high-temperature excess Ar; fig. 2A-C). Disturbed spectra with 235 intermediate age maxima, saddle-shaped spectra, or high levels of age discordance between 236 individual heating steps were excluded from modeling and interpretation. Age-spectrum steps 237 were modeled only if released below the point of sample breakdown due to partial melting 238 (usually at temperatures of $\sim 1100^{\circ} \mathrm{C}$ ). We used the Arvert code for thermal history inversion 239 (www.ees.lehigh.edu/EESdocs/geochron/software.html), which utilizes a Controlled Random 240 Search (CRS) algorithm to search for a family of suitable solutions (see supplementary material 241 for more information). The algorithm searches parameter space for thermal histories that 242 minimize misfit between observed and predicted age spectra and additional mineral ages using 243 the mean square of the weighted deviates (MSWD) as the objective function for assessing the 244 agreement between model predictions and observed data. Explicit high-temperature constraints, 245 variable heating and cooling rates, and additional apatite or zircon (U-Th)/He ages can be 246 included and modeled along with the K-feldspar age information. Thus, below we discuss those 247 samples that are most representative of the regional dataset and are reliable indicators of the 248 overall cooling histories for the southern craton.

\subsubsection{Western Superior Province, Ontario}

251 Sample \#70 is a tonalite-trondjhemite granite from the Neoarchean North Caribou Terrane of the 252 western Superior Province, one of the oldest Archean cratons in North America (Percival et al., 253 2006). Most of the rocks in this region record 3.1-2.6 Ga magmatic activity and hydrothermal 254 alteration (Kelly et al., 2017) and a nearby sample yields zircon and titanite U-Pb ages of $2858 \pm$ $2555 \mathrm{Ma}$ and $2854 \pm 7 \mathrm{Ma}$, respectively (Van Lankvelt et al., 2016). Ti-in-zircon thermometry 256 indicates zircon crystallization temperatures of $752 \pm 37^{\circ} \mathrm{C}$ (Van Lankvelt et al., 2016). Apatite 257 fission-track (AFT) ages from this region of Ontario are ca. 350-500 Ma (Kohn et al., 2005). A 258 single-grain apatite (U-Th)/He analysis for this sample yields a conventional (U-Th)/He age of $259531.5 \pm 11.5 \mathrm{Ma}(1 \sigma)$ and a continuous ramped heating $(\mathrm{CRH})$ corrected age of $403 \pm 40 \mathrm{Ma}(1 \sigma ;$ 260 McDannell et al. 2018). The $\mathrm{CRH}^{4} \mathrm{He}$ release spectrum for this sample reveals several discrete 261 He gas spikes throughout the duration of the laboratory heating experiment (see supplement 262 figure). Subsequent ion microprobe analysis on the CAMECA ims-1270 at UCLA and SEM 
263 imaging revealed that \#70 apatite is characterized by high U-bearing, $\sim 2 \mu \mathrm{m}$ xenotime

264 inclusions, which likely contribute to anomalous CRH behavior.

Sample WN-1 is an Archean granodiorite from the Winnipeg River Subprovince of the Superior craton from the Lac du Bonnet Batholith emplaced at $2665 \pm 20$ to $2568 \pm 23 \mathrm{Ma}$ (Everitt et al., 1996 and references therein). This sample was from a borehole core at $30.5 \mathrm{~m}$ depth and was previously dated via biotite ${ }^{40} \mathrm{Ar} /{ }^{39} \mathrm{Ar}$, yielding an age of $2291 \pm 27 \mathrm{Ma}$ (Hunt and Roddick, 1988). An apatite sample (URL-6-2) at nearly the same depth as WN-1 has an AFT age of $373 \pm$ 29 Ma (Feinstein et al., 2009). These AFT borehole data yield ages of ca. 370 to $250 \mathrm{Ma}$, 272 decreasing in age with depth.

274 Our K-feldspar ${ }^{40} \mathrm{Ar} /{ }^{39} \mathrm{Ar}$ data were modeled assuming monotonic cooling and yielded thermal 275 histories as follows. The majority of samples show cooling rates of $\sim 0.3^{\circ} \mathrm{C} / \mathrm{Ma}$ from ca. 1.9 to $2761.5 \mathrm{Ga}$ and relatively slower cooling rates of $\leq 0.1^{\circ} \mathrm{C} / \mathrm{Ma}$ from ca. 1.5 to ca. $1.1 \mathrm{Ga}$. Net cooling 277 over this entire interval of $0.8 \mathrm{Ga}$ was only on the order of $100^{\circ} \mathrm{C}$ (fig. 3). Superior craton ${ }^{40} \mathrm{Ar} /{ }^{39} \mathrm{Ar}$ spectra from samples \#70 and $\mathrm{WN}-1$ in particular display thermal histories indicative of prolonged mid-to-upper crustal residence during the Proterozoic, with time-integrated slow cooling on the order of $\sim 0.1^{\circ} \mathrm{C} / \mathrm{Ma}$ until ca. $1.0 \mathrm{Ga}$, when marginally faster cooling resumed to bring these rocks to the surface (fig. 3).

It is important to assess the assumption that these samples experienced only monotonic cooling. We use sample \#70 to illustrate this non-unique nature of thermal history modeling and establish the resolution and sensitivity of our feldspar thermal histories more generally (fig. 3D). Three monotonic and six non-monotonic thermal-history model inversions were performed under different starting conditions, i.e. permissible cooling rates, number of time nodes, explicit temperature constraints, and achievement of varying degrees of convergence. Both monotonic and reheating histories overlap very well over the portions of the model constrained by observations (fig. 3D), however models that allow reheating indicate that if it did occur, it would have been during the interval 1.45 to $1.1 \mathrm{Ga}$. High amounts of reheating $\left(>>200^{\circ} \mathrm{C}\right)$ erase $\mathrm{T}-\mathrm{t}$

292 information through thermal resetting of diffusion domains in K-feldspar, so our data imply that 293 reheating of any amount between $\sim 50^{\circ} \mathrm{C}$ up to $\sim 200^{\circ} \mathrm{C}$ is allowed. The best-fitting models favor 
294 minimal reheating of $\sim 50^{\circ} \mathrm{C}$ prior to $1.0 \mathrm{Ga}$, but, of critical importance still place this sample at 295 temperatures of $\sim 180-200^{\circ} \mathrm{C}$ near $1.1-1.0 \mathrm{Ga}$.

\subsubsection{Trans-Hudson Orogen, Saskatchewan}

298 The transition from the exposed Precambrian shield bedrock to Phanerozoic cover of the 299 Western Canada basin is exposed in north-central Saskatchewan. Southern Saskatchewan is 300 made up of multiple deformation fronts that welded the ca. 2.4 to 3.1 Ga Sask, Hearne, Rae, and 301 Wyoming cratons during ca. 1.9-1.8 Ga Trans-Hudson orogenesis and suturing of Laurentia 302 (Hoffman, 1988; Bickford et al., 2005). K-feldspar step-heating results from samples of the 303 Athabasca Basin margin in the Chipman Domain basement of the Snowbird Tectonic Zone are 304 tightly constrained by stratigraphy (Rainbird et al., 2007) and existing high-temperature titanite, 305 apatite, and rutile $\mathrm{U}-\mathrm{Pb}$ ages of ca. $1.90-1.75 \mathrm{Ga},{ }^{40} \mathrm{Ar} /{ }^{39} \mathrm{Ar}$ hornblende, muscovite, and biotite 306 ages of 1.78-1.72 Ga (Schneider et al., 2007), and low-temperature zircon and apatite (U-Th)/He 307 ages of 1.70-1.63 Ga and 0.71-0.55 Ga, respectively (Flowers et al., 2006a,b). All of these data 308 define an early rapid cooling event that left Athabasca rocks at or near the surface since ca. 1.6$3091.5 \mathrm{Ga}$.

311 Our Athabasca K-feldspar data show excellent agreement with existing thermochronologic data 312 (fig. 3). Of most significance, the two K-feldspar samples from the Athabasca Basin margin 313 (samples 02-123A and 02-76B) yield the fast-cooling thermal histories one would predict from 314 existing independent thermochronological results. This is a strong argument for the validity of 315 applying the ${ }^{40} \mathrm{Ar} /{ }^{39} \mathrm{Ar}$ MDD method to very old rocks, and indicates our other thermal-history 316 results are reliable.

318 Thermal histories derived from other Athabasca samples are consistent with results obtained 319 from neighboring terranes. Sample SK-KM-01 shows either slow cooling from ca. 1.5 to ca. 1.1 320 Ga or modest reheating from ca. 1.3 to $1.1 \mathrm{Ga}$ (sample furthest south; fig. 1). Although, the K321 feldspar age spectrum from the southern Athabasca basin (SK-KM-03) shows some evidence of 322 low-temperature thermal alteration (Lovera et al., 2002), the modeled T-t history aligns well with 323 the samples from the northern Athabasca basin margin. Whereas the central Saskatchewan 
324 sample from the Sask craton (SK-KM-01) exhibits a T-t history similar in style and timing to the 325 Superior Province samples.

\subsubsection{Grenville Province, Quebec}

328 Sample OL13 is a syenogranite from the CMB, $\sim 100 \mathrm{~km}$ northwest of Ottawa. This area underwent upper-amphibolite facies metamorphism at temperatures and pressures of $700 \pm 50^{\circ} \mathrm{C}$ and 6.5-7.5 kbar (Kretz, 1994) during the Elzivirian and Ottawan phases of the Grenville orogeny. Biotite from this sample yielded a ${ }^{40} \mathrm{Ar} /{ }^{39} \mathrm{Ar}$ total-gas age of ca. $0.88 \mathrm{Ga}$ and a nearby sample from the same outcrop has a hornblende ${ }^{40} \mathrm{Ar} /{ }^{39} \mathrm{Ar}$ age of $0.98 \mathrm{Ga}$ (Schneider et al., 2013). Moreover, titanite from hornblende-pyroxene granites in the CMB yield U-Pb ages of ca. $1.02 \mathrm{Ga}$ (Kennedy et al., 2010), allowing the higher temperature Ar systems to constrain 300$500^{\circ} \mathrm{C}$ from nearly $1.0 \mathrm{Ga}$ to $0.8 \mathrm{Ga}$. Collectively these data suggest orogenic cooling of $\sim 2^{\circ} \mathrm{C}$ Ma. Our K-feldspar MDD monotonic thermal histories imply rapid cooling through $\sim 250$ $200^{\circ} \mathrm{C}$, followed by post-orogenic slow cooling of $\sim 0.1-0.2^{\circ} \mathrm{C}$ (fig. 3B). Again, these K-feldspar results are consistent with existing independent geochronological results.

\subsection{Summary of results}

341 Like for all thermochronometers, the use of the ${ }^{40} \mathrm{Ar} /{ }^{39} \mathrm{Ar}$ MDD method to resolve time-

342 temperature histories over protracted periods requires that diffusion mechanisms and kinetics 343 determined in the laboratory over short timescales apply to much longer intervals; i.e., the 344 assumption is that there are no additional slow, low-temperature argon-loss mechanisms that 345 become significant at billion-year timescales (fig. 2D-F). The agreement of our MDD results 346 with independent geochronologic studies of the Athabasca Basin and the Grenville Province 347 localities clearly confirms that the ${ }^{40} \mathrm{Ar} /{ }^{39} \mathrm{Ar}$ MDD method works and can be reliably applied to 348 very old rocks, providing confidence that other samples are equally informative.

350 As a result, it is significant that combined ${ }^{40} \mathrm{Ar} /{ }^{39} \mathrm{Ar}$ MDD K-feldspar data and high- and low351 temperature thermochronology reveal much different histories for samples from the southern 352 Canadian Shield (fig. 3B-D). Monotonic cooling-only scenarios exhibit broad agreement 353 between locations in the south-central craton for a period of very slow cooling from ca. 1.5-1.0 $354 \mathrm{Ga}$, suggesting that these rocks were at elevated temperatures of $\sim 200^{\circ} \mathrm{C}$ near $1.0 \mathrm{Ga}$ and did not 
355 cool quickly to near-surface temperatures. Scenarios allowing reheating indicate that if heating 356 occurred, it was prior to $1.0 \mathrm{Ga}$, and over a prolonged period coincident with the duration of the 357 Grenvillian orogeny (ca. $200-300$ m.y.) and $\approx 50^{\circ} \mathrm{C}$ to $200^{\circ} \mathrm{C}$ in magnitude. Nonetheless, both 358 monotonic and reheating histories still suggest rocks were at temperatures near $200^{\circ} \mathrm{C}$ in the 359 latest Meso- to earliest Neoproterozoic. Moreover, Schwartz and Buchan (1982) examined the 360 thermal overprinting of remnant magnetization on 1.24 Ga Sudbury dikes in southern Ontario. 361 They calculated the country rock was at a paleo-depth of $9.5 \pm 2.5 \mathrm{~km}$ and temperatures of $267 \pm$ $36211^{\circ} \mathrm{C}$ at the time of dike emplacement, in general agreement with our ${ }^{40} \mathrm{Ar} /{ }^{39} \mathrm{Ar}$ data.

364 Rocks at temperatures of $200^{\circ} \mathrm{C}$ in the late Proterozoic pose an interesting problem. Invoking 365 monotonic cooling and an average cratonic geothermal gradient of $20^{\circ} \mathrm{C} / \mathrm{km}$, such temperatures 366 would imply that these rocks were in the mid-crust. If reheating occurred via long-term burial, 367 thick sediment packages would be required, and following peak reheating, rocks would then 368 need to be re-exhumed. Therefore, significant burial heating is an unlikely mechanism, although 369 the next sections discuss possible contributing mechanisms to explain these thermal histories. 

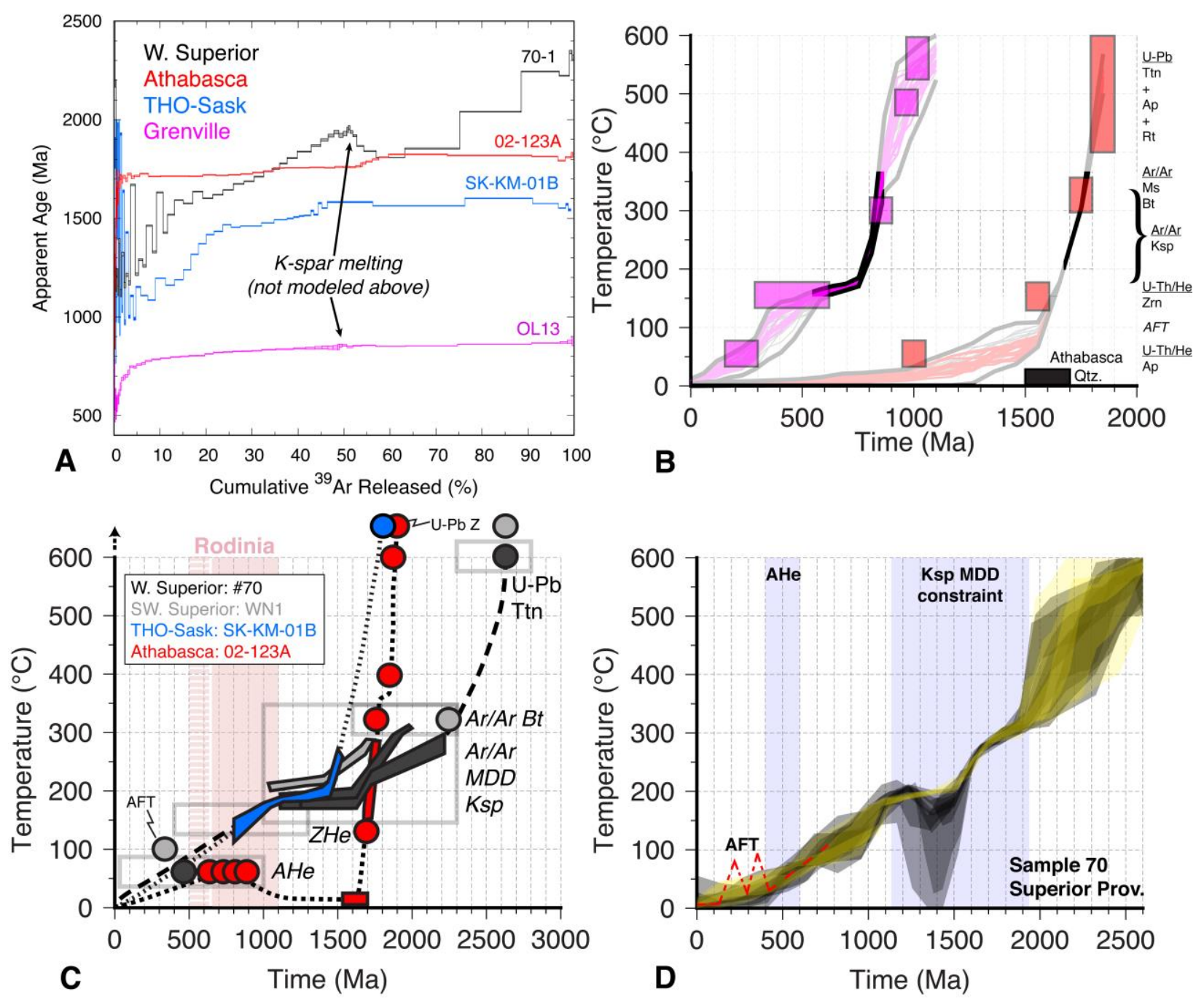

371 Figure 3. (A) K-feldspar MDD ${ }^{40} \mathrm{Ar} /{ }^{39} \mathrm{Ar}$ age spectra from the Western Superior Province (\#70; black), 372 Athabasca Basin sample (02-123A; red), THO-Sask craton (SK-KM-01B; blue) and the Grenville 373 Province (OL13; violet). (B) Monotonic cooling-only T-t inversions corresponding to colored spectra in 374 fig. 3A (sample $70 \mathrm{~T}$-t monotonic and reheating-allowed results in fig. 3D). These models show excellent 375 agreement with independent higher- and lower-temperature thermochronologic constraints indicated by 376 colored boxes. The MDD spectra can only constrain T-t histories from $\sim 150$ to $350^{\circ} \mathrm{C}$, illustrated by the 377 T-t envelopes for the 15 best solutions bounded by heavy black lines; steps with excess Ar early in gas 378 release and those after $\mathrm{K}$-feldspar melting at $\sim 1100^{\circ} \mathrm{C}$ were not modeled. Black box is constraint given by 379 depositional age range of Lake Athabasca sediments. Full age-constraint references are given in 380 supplementary material. (C) Summary of constrained T-t envelopes for monotonic-only K-feldspar MDD 381 thermal histories of samples from the Western Superior Province (Samples \#70 and WN-1: black and 382 gray symbols), Sask craton sample SK-KM-01B from central Saskatchewan (blue symbols), and a highly 383 constrained Athabasca sample from the Chipman Domain (red symbols); refer to figure 2 for other age 384 spectra that are not shown in fig. 3A. Colored dots correspond to bracketing high and low-temperature 385 data for each sample. Gray boxes show the typical temperature range addressed by other 386 thermochronologic systems. Notice truncated y-axis as U-Pb in zircon closure temperatures are in excess of $850-900^{\circ} \mathrm{C}$. Pink band shows the time span of the Rodinia supercontinent from ca. 1.1 Ga to breakup near ca. 0.7-0.6 Ga. Athabasca constraints from Flowers et al. (2006a,b) (D) Sample \#70 (from NCT, 
western Superior Province) thermal-history inversions showing the difference between three monotonic cooling models (yellow envelopes) and six models allowing reheating (black envelopes). Both sets of solutions place these rocks near temperatures of $300^{\circ} \mathrm{C}$ at ca. $1.8 \mathrm{Ga}$ and $>150-200^{\circ} \mathrm{C}$ at ca. $1.0-1.1 \mathrm{Ga}$. Regions explicitly constrained by ${ }^{40} \mathrm{Ar} /{ }^{39} \mathrm{Ar}$ and apatite (U-Th)/He data are shown. Dashed line shows Phanerozoic T-t path from burial/exhumation histories derived from summarized AFT data of Kohn et al. (2005) and Feinstein et al. (2009) during Paleozoic and Mesozoic burial of up to $\sim 1.1-1.2 \mathrm{~km}$ from building of the Appalachians. Zrn = zircon, Ttn = titanite, Rt = Rutile; Ms = Muscovite; Bt = biotite; Ksp $=\mathrm{K}$-feldspar; $\mathrm{AHe}=$ apatite $(\mathrm{U}-\mathrm{Th}) / \mathrm{He} ; \mathrm{ZHe}=\operatorname{zircon}(\mathrm{U}-\mathrm{Th}) / \mathrm{He} ; \mathrm{AFT}=$ apatite fission-track

\section{Discussion}

Samples from the Canadian Shield bedrock at Lake Athabasca and in the Grenville Province document and support the more 'traditional' views of craton stability and rapid post-orogenic decay, respectively, because their thermal histories suggest rapid exhumation to the surface followed by relative stasis. However, unexpectedly some regions appear to have behaved very differently, suggesting more complex or protracted thermal histories and thus more complex lithospheric evolution. Thermal histories from the Archean-Paleoproterozoic southern Canadian Shield (Western Superior Province and Sask craton) indicate rocks there were instead at temperatures near $200^{\circ} \mathrm{C}$ at $1.0 \mathrm{Ga}$. No matter how they were achieved, temperatures of $200^{\circ} \mathrm{C}$ would represent a depth of about $10 \mathrm{~km}$ using the maximum geothermal gradient estimate for the Superior Province from Jaupart et al. (2014). This depth and the temperature it is based on provide a serious challenge to conventional views of long-term cratonic stability.

\subsection{Burial heating and geotherm variability}

One interpretation of our MDD data is that some or all of the $200^{\circ} \mathrm{C}$ temperatures at $1 \mathrm{Ga}$ were the result of reheating due to sediment burial or changes in heat flow. To achieve $180-200^{\circ} \mathrm{C}$ of burial reheating, significant accommodation space and sediment source would have been required. From ca. 1.3-1.0 Ga the Superior Province witnessed deformation from Grenvillian contraction and foreland sedimentation on one side and MCR extension on the other. If one attributes all or some of the reheating to burial, an explanation would be required as to how such a horizontally and vertically extensive package of sediments could be deposited at $1 \mathrm{Ga}$, far inboard of the Grenville orogen. If this were the case, there would remain a reasonably thick rock column to be removed afterwards, since our samples were collected from the current bedrock surface. It has been recognized, however, that the central craton has undergone platform sedimentation numerous times since ca. $2 \mathrm{Ga}$ and the spatially-dispersed sediments found across 
423 the landscape suggest that most of Laurentia was cyclically buried by sediment in the past 424 (Davidson, 2008). Detrital zircon provenance studies and paleo-current markers also reveal that 425 large continental-scale fluvial networks transported sediments shed from the Trans-Hudson 426 orogen (Rainbird et al., 2007) and later high topography of the Grenville orogen (Rainbird et al., 427 1992). These extensive fluvial systems locally buried the craton in a veneer of sediment up to 1 $428 \mathrm{~km}$ thick. However, it is difficult to assert that the majority of the southeastern Canadian Shield 429 experienced sheet-like deposition thick enough to appreciably reheat K-feldspar MDD samples.

431 To test this, we used a simple model of a steady-state crustal geothermal gradient to estimate the 432 effects of burial heating resulting from $5 \mathrm{~km}$ of sediments overlying a $10 \mathrm{~km}$ thick radiogenic 433 upper crust. The model incorporated moderate bulk crustal heat production $\left(A_{l}\right)$ of $3 \mu \mathrm{W} / \mathrm{m}^{3}$, 434 basin heat production $\left(A_{2}\right)$ of $5 \mu \mathrm{W} / \mathrm{m}^{3}$, surface temperature of $10^{\circ} \mathrm{C}$, basal heat flow of 30 $435 \mathrm{~mW} / \mathrm{m}^{2}$, and assumed uniform thermal conductivity $(K)$ of $2.5 \mathrm{~W} /(\mathrm{m} \cdot \mathrm{K})$. The base of the basin 436 sediments would reach temperatures of $125^{\circ} \mathrm{C}$; therefore, an intracratonic basin would have to be 437 greater than $5 \mathrm{~km}$ thick to achieve temperatures near those experienced by our rock samples, 438 which seems unreasonable for this setting. Heating to $200^{\circ} \mathrm{C}$ at $5 \mathrm{~km}$ depth could be achieved 439 through a combination of higher basin heat production, a thicker radiogenic upper crust, or 440 greater basal heat flow. This end-member burial scenario is possible but improbable. Moreover, 441 there is still no evidence of any proximal intracratonic basins of appropriate Mesoproterozoic 442 age, and most of the nearby preserved sediments were shed prior to and after Laurentian 443 assembly at ca. 1.8 Ga (Davidson, 2008).

445 It seems unlikely, at least under current views about cratonic evolution, that $200^{\circ} \mathrm{C}$ temperatures 446 at shallow depths could have been related to an abnormal geothermal gradient, and not burial, 447 because thermal gradients approaching $40-50^{\circ} \mathrm{C}$ or greater would have been required and 448 sustained on the order of a hundred million years or more to match the thermal-history model 449 results. Most geothermal perturbations are short-lived. An estimate of the Paleoproterozoic 450 steady-state geotherm of the Witwatersrand Basin is $27^{\circ} \mathrm{C} / \mathrm{km}$ with an increase to $\sim 40^{\circ} \mathrm{C} / \mathrm{km}$ 451 during $2 \mathrm{Ga}$ Bushveld magmatism and mafic underplating that lasted for <30 m.y. before 452 returning to steady-state conditions (Frimmel, 1997). At the scale of the lithosphere, plume-head 453 thermal diffusion effects have been modeled for the Great Meteor Hotspot of the northeastern 
454 North American craton, and a $500^{\circ} \mathrm{C}$ anomaly initially confined to the lower $50 \mathrm{~km}$ of the 455 cratonic lithosphere decays to $80^{\circ} \mathrm{C}$ at $200 \mathrm{~km}$ depth over $120 \mathrm{~m}$.y., while the middle to upper 456 crust records very little perturbation (Eaton and Frederiksen, 2007). Therefore, it is reasonable to 457 believe that thermal diffusivity through thick cratonic lithosphere is long (ca. $10^{9}$ years) and the 458 amount of basal heat required to substantially warm the middle and upper crust is high.

\subsection{Erosional exhumation via isostasy}

461 Whether there was reheating or not, it is not feasible to obtain $10 \mathrm{~km}$ of basement exhumation 462 through simple erosional isostatic return over the last 1 billion years because reasonable values 463 of upper/lower crust and mantle densities (e.g. Schmandt et al., 2015) would require a crustal 464 thickness of over $90 \mathrm{~km}$ at $1 \mathrm{Ga}$ to permit this much total exhumation. Erosion of this amount is 465 also conceptually difficult, given the widely assumed low continental freeboard that one might infer from such slow cooling between $2 \mathrm{Ga}$ and $1 \mathrm{Ga}$. The "constant freeboard model" asserts 467 that under isostatic-equilibrium conditions, the denudation of exposed cratonic terranes and accumulation of sediments on low-lying craton margins leads to continental elevations trending towards equilibrium with mean sea level over long timescales (Eriksson et al., 2006). This carries implications for the erosional potential at $1 \mathrm{Ga}$, where any significant cratonic topography would have been substantially eroded and the continental interior would have to be above sea level for excess elevation to be isostatically balanced by crustal thickness.

There are also discrepancies regarding total erosion levels and crustal thickness approximations. Abbott et al. (2000) estimate that the worldwide total crustal erosion that occurred in Archean and early Proterozoic terranes was minimal, ranging from 2.5-7.8 km (4.1 km avg.) and 1.65-4.4

$477 \mathrm{~km}(2.5 \mathrm{~km}$ avg.), respectively. Pressure-temperature estimates of rocks exposed at the surface 478 (fig. 4) also demonstrate that large portions of the western Superior Province have been exhumed 479 a total of 10-15 km ( 4-6 kbar), whereas present Moho depths are at $40 \mathrm{~km}$, which places limits 480 on maximum crustal thicknesses on the order of $\sim 45-60 \mathrm{~km}$ (Percival et al., 2006; Percival et al., 481 2012). Integrated geothermal constraints and prior P-T studies suggest that exposed North 482 Caribou terrane metamorphic rocks in the Western Superior Province were eroded $\sim 11 \mathrm{~km}$ total 483 (Jaupart et al., 2014). With the known erosion levels and estimated original crustal thickness, 484 exhumation-driven cooling from $\sim 200^{\circ} \mathrm{C}$ at $1.0 \mathrm{Ga}$ would require post-Archean crustal 
thickening, with the majority of total cratonic exhumation being delayed until the late

486 Proterozoic. In short, petrologic observations combined with our K-feldspar MDD data would 487 suggest that exhumation of virtually all of the southern Canadian Shield was deferred to (and 488 after) ca. $1 \mathrm{Ga}$.

\subsection{Magmatic underplating}

491 Crustal thickening by underplating can reconcile the renewed cooling seen in our thermal

492 histories with reasonable levels of crustal erosion. Mafic underplating is integral to many models 493 of Archean-Proterozoic geodynamics and crustal growth, where high-density material is added to 494 the base of the crust (Thybo and Artemieva, 2013). The emplacement of 10-25 km of 495 underplated material can rapidly thicken and add significant crustal volume under normal 496 lithospheric thermal conditions (Cox, 1993; Furlong and Fountain, 1986). Adiabatic 497 decompression of the mantle forms melt that typically has a density of $3000-3100 \mathrm{~kg} / \mathrm{m}^{3}$, which

498 lies between typical mantle and crustal values, therefore increasing the potential for mafic-melt 499 trapping in the lower crust that displaces denser lithospheric mantle thus producing surface uplift 500 (Allen and Allen, 2013). The high seismic velocities observed in the lower crust of underplated 501 regions seems to verify this (Thybo and Artemieva, 2013), and underplating has been proposed 502 for other cratons such as the Kaapvaal craton in South Africa that experienced crustal inflation 503 and uplift during Karoo province magmatism (Cox, 1993).

\subsubsection{Underplating at the Mid-Continent Rift}

506 The Mid-Continental Rift affected the Superior craton at ca. 1.1 Ga and various models exist for 507 initiation, either a hot mantle plume that impinged on the lower lithosphere (e.g. Nicholson and 508 Shirey, 1990) or as a far-field extensional response to compressional stresses during the 509 Grenville orogeny (e.g. Whitmeyer and Karlstrom, 2007), or a combination of the two (Stein et 510 al., 2015). Northward propagation of the MCR was inhibited by the strong Superior lithosphere, 511 and the shape and position of the rift was influenced by the stable craton margin (Ola et al., 512 2016). There is evidence for basaltic underplating of the Archean lower crust during the $1.1 \mathrm{Ga}$ 513 failed rifting of the mid-continent (e.g. Behrendt et al., 1990; Tréhu et al., 1991) with a 10-20 km 514 thick layer between the lower crust and upper mantle interpreted as underplated magmatic 515 material (Zhang et al., 2016). Other seismic studies suggest that the crust is unusually thick at the 
516 MCR from reactivation and underplating during late stages of the Grenville orogeny (e.g. Shen et

517 al., 2013). Geophysical modeling also shows a similar Moho density contrast interpreted as

518 thickened crust due to mafic underplating that is $>15 \mathrm{~km}$ thick at the base of the southwestern

519 Superior crust that occurred during Trans-Hudson $(1.8 \mathrm{Ga})$ suturing of the Yavapai-Superior-

520 Wyoming blocks (Thurner et al., 2015).

\section{$522 \quad$ 3.3.2 Underplating in the Superior Province}

523 In general, Proterozoic crust is consistently thicker $(40-55 \mathrm{~km})$ and is characterized by greater 524 lower crustal seismic velocities, when compared to Archean terranes (Durrheim and Mooney, 525 1991). The North Caribou Terrane is the core of the western Superior Province and is contrarily 526 characterized by thicker crust (40-43 km), given its Archean affinity (Percival et al., 2012; Perry 527 et al., 2002). There is also regional evidence for thickened crust, with thickening from $40 \mathrm{~km}$ in 528 the NCT to $45 \mathrm{~km}$ towards Lake Superior at the locus of MCR rifting. This is markedly different 529 from the eastern Superior craton, which is $\sim 35 \mathrm{~km}$ thick on average (Perry et al., 2002). The 530 greater crustal thickness in the western Superior compared to the eastern Superior and thickening 531 towards the MCR supports the compiled worldwide observations for post-Archean underplating 532 and crustal thickening to first-order (Durrheim and Mooney, 1991; Thybo and Artemieva, 2013).

534 The lower crust-upper mantle anomaly that exists in the western Superior Province has been 535 interpreted to be the result of Archean imbricate oceanic slab accretion (in the Wabigoon 536 Subprovince) under the NCT during lithospheric assembly that appears as Moho-penetrating 537 high-velocity regions in seismic profiles (Musacchio et al., 2004; White et al., 2003; fig. 4). 538 Nitescu et al. (2006) hypothesize that the oceanic slab argument is not conclusive and that 539 continuity in lower crustal densities align more with a model of post-accretion thermal softening 540 and lower crustal reworking. They argue that the mass anomalies within the lower crust of the 541 Wabigoon Province and those terranes to the south instead represent dense underplated, 542 anisotropic mafic rocks from MCR extension and magmatism.

544 Thermobarometry and the compositional differences with depth (fertile vs. depleted) found 545 between garnets in the Proterozoic Kyle Lake and Paleozoic-Mesozoic Attawapiskat kimberlites 546 (just east of Kyle Lake; fig. 4) in the western Superior Province signify a modified mantle 
composition or reworked structure between parts of the western province due to extension and basalt emplacement (Scully et al., 2004). The thickened crust of the rift flanks experienced uplift due to increased buoyancy and the "topographic doming" model of Allen et al. (1992) proposes MCR melting from a mantle plume source affected a large portion of the western Superior lower crust with underplating occurring up to $650 \mathrm{~km}$ from the rift itself (fig. 4). This model is reinforced by the aforementioned high-density, lower-crustal layer thickening towards the MCR and the presence of synchronous Keweenawan dikes (and kimberlites) north of Lake Superior 554 (Ernst and Bleeker, 2010), which are typically believed to be the surface expression of 555 underplated mafic rocks (Nelson, 1991).

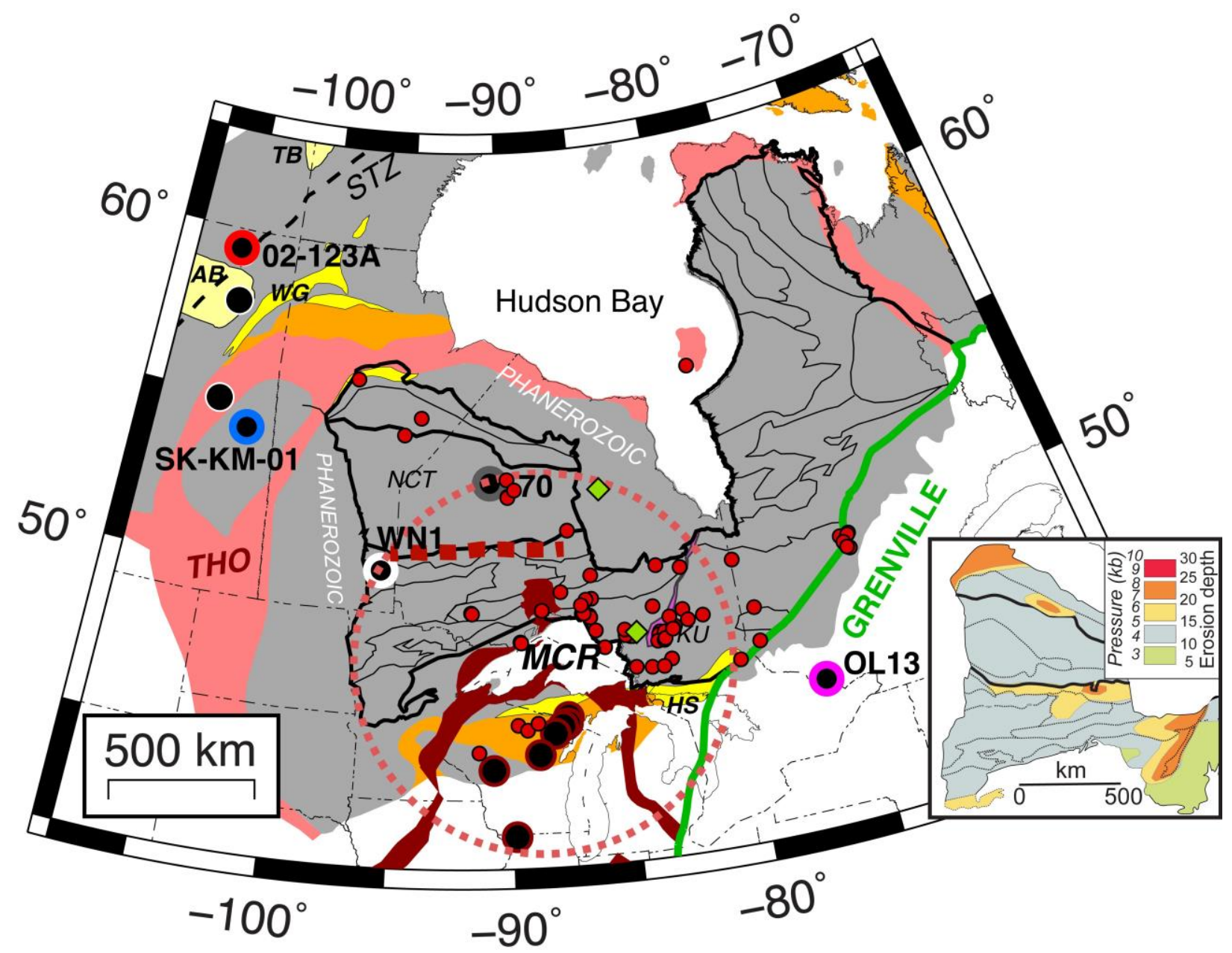

Figure 4. Map of the southern Canadian Shield modified from Whitmeyer and Karlstrom (2007) with geologic sub-terranes of the Superior Province outlined in black from Percival et al. (2006). Inset map shows erosion depths in $\mathrm{km}$ and P-T estimates across the western Superior Province, adapted from Percival et al. (2012). K-feldspar MDD samples dated in this study via ${ }^{40} \mathrm{Ar} /{ }^{39} \mathrm{Ar}$ are shown by black dots and the MCR likely disturbed those with dark red outlines (see supplement for age spectra). Small red dots are from the Geological Survey of Canada geochronology database filtered by $0.95-1.2 \mathrm{Ga}$ date 
563

564

565

566

567

568

569

570

571

572

573

574

575

576

577

578

579

580

581

582

583

584

585

586

587

588

589

590

591

592

593

594

595 596

range, largely representing mafic dike ages using various dating methods. Note: the red points in NW Superior are likely related to the ca. 1.26 Mackenzie dike swarm originating in the Slave craton up to $3000 \mathrm{~km}$ to the northwest. The dark red dashed line near the southern NCT boundary is the approximate high seismic velocity region from White et al. (2003); Musacchio et al. (2004) and gravity anomalies of Nitescu et al. (2006) interpreted as a result of MCR underplating. Red dashed circle is the region that could theoretically be affected by topographic doming up to $650 \mathrm{~km}$ away from the MCR nucleus, from Allen (1992). Light green diamonds are Kyle Lake (north) and Abitibi kimberlites (south) of ca. $1.1 \mathrm{Ga}$ age. All other map elements are referenced in figure 1.

The western Superior Province shows evidence of significant deformation related to dike swarms and rifting at ca. 1.27 Ga from the Mackenzie plume and dike system (in the Slave Province far to the northwest) and the ca. 1.1 Ga MCR mantle plume (fig. 4). This later magmatism produced a $>15 \mathrm{~km}$ underplated, thickened crust at the MCR, which tapers to approximately $\leq 10 \mathrm{~km}$ thickness to the north in the western Superior Province, based on the aforementioned studies showing a high velocity lower crustal layer (e.g. Musacchio et al., 2004; Nitescu et al., 2006). Lower-crustal magmatic underplating causes thickening and drives isostatic compensation to account for added mass. To model the appropriate crustal response, we used typical crustal densities, as well as those from Thurner et al. (2015) of 2950,3100 , and $3300 \mathrm{~kg} / \mathrm{m}^{3}$ for the crust, underplate material, and mantle, respectively, to simulate isostatic uplift and erosion (table 1). Using equations from Allen and Allen (2013), under normal lithospheric conditions with the surface at sea level, the pressure at depth, $y_{L}$ at the base of the lithosphere is:

$$
y_{c} \rho_{c} g+\left(y_{L}-y_{c}\right) \rho_{m} g
$$

Where $g$ is gravitational acceleration, $Y_{c}$ and $Y_{L}$ are the thickness of the crust and lithosphere and $\rho_{c}$ and $\rho_{m}$ are the crustal and mantle densities, respectively. The pressure at the same depth, under uplifted lithosphere with an underplate $(H)$ is given as:

$y_{c} \rho_{c} g+H \rho_{h} g+\left(y_{L}-y_{c}-H+U\right) \rho_{m} g$

Equation (3) describes the uplift (U) relationship under Airy isostasy conditions and the balance of lithospheric columns at the base of the lithosphere (compensation depth); where $H$ is the underplate thickness, $\rho_{h}$ is the density of the underplate, and $\rho_{m}$ is the density of the mantle. 


$$
U=H\left(1-\frac{\rho_{h}}{\rho_{m}}\right)
$$

599 Erosional denudation $(D)$ is included, where $\rho_{c}$ is the crustal density:

$$
D=H\left(\frac{\rho_{m}-\rho_{h}}{\rho_{m}-\rho_{c}}\right)
$$

603

604 Underplate thicknesses of 3 to $10 \mathrm{~km}$ (table 1) produce respective isostatic uplift amounts of $605 \sim 200$ to $\sim 900 \mathrm{~m}$, resulting in $\sim 1700$ to $6000 \mathrm{~m}$ of denudation (assuming no change in surface 606 elevation).

607

Table 1: Isostatic uplift and denudation for magmatic underplating

\begin{tabular}{cccccc}
\hline Underplate, $\mathrm{H}(\mathrm{m})$ & $\rho_{c}\left(\mathrm{~kg} \mathrm{~m}^{-3}\right)$ & $\rho_{h}\left(\mathrm{~kg} \mathrm{~m}^{-3}\right)$ & $\rho_{m}\left(\mathrm{~kg} \mathrm{~m}^{-3}\right)$ & $\begin{array}{c}\text { Uplift, U } \\
(\mathrm{m})\end{array}$ & $\begin{array}{c}\text { Denudation, } \\
\mathrm{D}(\mathrm{m})\end{array}$ \\
\hline 3000 & 2800 & 3000 & 3300 & 273 & 1800 \\
5000 & 2800 & 3000 & 3300 & 455 & 3000 \\
$\mathbf{1 0 0 0 0}$ & $\mathbf{2 8 0 0}$ & $\mathbf{3 0 0 0}$ & $\mathbf{3 3 0 0}$ & $\mathbf{9 0 9}$ & $\mathbf{6 0 0 0}$ \\
15000 & 2800 & 3000 & 3300 & 1364 & 9000 \\
20000 & 2800 & 3000 & 3300 & 1818 & 12000 \\
\hline 3000 & 2950 & 3100 & 3300 & 182 & 1714 \\
5000 & 2950 & 3100 & 3300 & 303 & 2857 \\
10000 & 2950 & 3100 & 3300 & 606 & 5714 \\
15000 & 2950 & 3100 & 3300 & 909 & 8571 \\
20000 & 2950 & 3100 & 3300 & 1212 & 11429
\end{tabular}

608

609

610

611

612

613

614

615

616

\section{7}

618

619

Table 1. The role of magmatic underplating of variable thickness and density is shown. The relation of crustal density changes inducing an isostatic response causing uplift and corresponding erosion at the surface. Mafic underplating of typical thicknesses for the crust between 3-20 km (variable density) can cause up to $\sim 275-1800 \mathrm{~m}$ of uplift, resulting in $\sim 2-12 \mathrm{~km}$ of erosion. Note: multiplying the underplate thickness by a factor of 0.6 yields the amount of denudation for typical crustal/underplate/mantle densities of $2800 / 3000 / 3300 \mathrm{~kg} / \mathrm{m}^{3}$. The $10 \mathrm{~km}$ underplate thickness in bold is a likely scenario for the western Superior Province from geophysical and gravity data interpretations.

\subsection{Summary of mechanisms to explain T-t histories}

Our key finding is that ${ }^{40} \mathrm{Ar} /{ }^{39} \mathrm{Ar} \mathrm{K}$-feldspar MDD data establish that rocks in the southern Canadian Shield were at $\sim 200^{\circ} \mathrm{C}$ at ca. $1 \mathrm{Ga}$. Our preferred mechanism to provide the required exhumation required to expose these rocks is magmatic underplating, which is a feasible way to 
621 thicken the crust in the Proterozoic and cause isostatic disequilibrium that would necessitate 622 erosional re-equilibration. Assuming a $20^{\circ} \mathrm{C} / \mathrm{km}$ geothermal gradient, monotonic cooling-only 623 thermal histories for the western Superior Province indicate that the surface rocks from which 624 our feldspar samples were taken were at depths of up to $10 \mathrm{~km}$ in the crust at ca. $1.0 \mathrm{Ga}$. Extreme 625 crustal thicknesses of $\sim 90 \mathrm{~km}$ would be required if rocks were simply isostatically exhumed over 626 the past 1 billion years. Our data imply that if rocks resided in the middle crust, then the majority 627 of craton unroofing was delayed until Rodinian time near the end of the 'Boring Billion.' 628 Alternatively, reheating between ca. $1.45-1.1 \mathrm{Ga}$ on the order of $\sim 50-200^{\circ} \mathrm{C}$ is allowed by the $629{ }^{40} \mathrm{Ar} /{ }^{39} \mathrm{Ar}$ MDD thermal histories, depending on the amount of pre-heating exhumation. Our best

630 thermal history models favor the lower end of this reheating range near $\sim 50^{\circ} \mathrm{C}$. Reheating of this 631 magnitude could be achieved through $<3 \mathrm{~km}$ of sedimentary burial or significant upper crustal 632 heating (having no obvious source) prior to $1.0 \mathrm{Ga}$. Ruling out a purely thermal anomaly in the 633 shallow crust, burial of partially exhumed exhumed metamorphic rocks still leaves the samples at 634 depth at $1.0 \mathrm{Ga}$. However, monotonic thermal histories seem preferable, as there is no 635 sedimentary evidence to support moderate, widespread burial in many areas, nor evidence of a 636 sustained elevated crustal geotherm that would have to be maintained over tens to hundreds of 637 millions of years. The time span of the sub-Cambrian Great Unconformity suggests that erosion 638 was the more dominant process across the exposed Laurentian shield at the end of the 639 Proterozoic.

\section{Conclusions}

642 Our ${ }^{40} \mathrm{Ar} /{ }^{39} \mathrm{Ar}$ MDD K-feldspar data fill a large observational gap and yield thermal histories

643 entirely consistent with other geochronologic and geologic information available for younger 644 cratonic terranes: Athabasca Basin and Grenville rocks show thermal histories of rapid cooling 645 and exhumation, in agreement with sedimentary data and high-temperature geochronology - and 646 our K-feldspar age spectra lend further support for this observation. ${ }^{40} \mathrm{Ar} /{ }^{39} \mathrm{Ar}$ age spectra and 647 thermal-history solutions from southern craton localities suggest very slow cooling of $648<0.5^{\circ} \mathrm{C} / \mathrm{Ma}$ throughout the Earth's middle age, whereas histories allowing reheating permit some 649 minor burial prior to ca. $1.0 \mathrm{Ga}$. Despite these subtle differences, the most important point is that 650 regardless of the type of history, southern craton rocks that are now at the surface were at 651 temperatures of $\sim 200^{\circ} \mathrm{C}$ in the latest Proterozoic. 
653 The known levels of total erosion and P-T constraints on the total crustal thickness in the western

654 Superior Province put limits on the regional exhumation history. Proterozoic slow cooling 655 requires crustal thickening on the order of $\sim 10 \mathrm{~km}$ near $1.0 \mathrm{Ga}$ to permit the necessary uplift and 656 erosion to explain the thermal histories derived from ${ }^{40} \mathrm{Ar} /{ }^{39} \mathrm{Ar}$ data. We argue that regional magmatic underplating due to ca. $1.1 \mathrm{Ga}$ Mid-Continent rifting thickened the crust and caused 658 exhumation beginning in the very latest Meso- to early Neoproterozoic. This is supported by 659 regional geophysical data that reveals underplating and crustal thickening adjacent to the Mid660 Continental Rift in the western Superior Province. Ultimately, there is an issue with timing 661 regarding the amount of exhumation \pm burial prior to $1.0 \mathrm{Ga}$ and the estimate of the actual crustal 662 depth of our samples at $1.0 \mathrm{Ga}$. Our preferred scenario is that after Archean-Paleoproterozoic 663 tectonism, there was $\sim 3-5 \mathrm{~km}$ of exhumation in (linked) combination with allowing up to $\sim 1-3$ $664 \mathrm{~km}$ of Mesoproterozoic burial, followed by $\sim 6-9 \mathrm{~km}$ of exhumation starting at ca. $1.0 \mathrm{Ga}$. 665 Integrated thermochronology and geologic records thus suggest that most cratonic exhumation 666 was delayed until the early Neoproterozoic, during this previously unrecognized exhumation 667 event. Large-scale denudation contributed to the development of the Great Unconformity in 668 North America, preceding the recognized epeirogenic burial and exhumation episodes occurring 669 during the early Phanerozoic.

\section{Acknowledgements}

672 We thank An Yin for editorial handling and T. Mark Harrison and an anonymous reviewer for 673 efficient and insightful reviews that helped clarify the manuscript. We would also like to thank 674 Rob Rainbird at the Geological Survey of Canada, Ottawa for offering additional comments on 675 the manuscript. We also thank Rebecca Flowers at the University of Colorado, Boulder for 676 providing Athabasca samples and Ryan Morelli at the Saskatchewan Geologic Survey for access

677 to granite cores. Thanks to Nancy Joyce of the GSC-Ottawa geochronology lab for finding 678 information about a long-lost sample and thanks to Bruce Idleman for assistance with sample 679 preparation, irradiation logistics, and in running samples at the Lehigh noble-gas laboratory. 680 Natural Resources Canada, Land and Minerals sector, Geological Survey of Canada: PPI 681 contribution ID\# 36455. 


\section{References}

Abbott, D., Sparks, D., Herzberg, C., Mooney, W., Nikishin, A., and Zhang, Y. S., 2000, Quantifying Precambrian crustal extraction: the root is the answer: Tectonophysics, v. 322, no. 1, p. 163-190.

Alexandre, P., Kyser, K., Thomas, D., Polito, P., and Marlat, J., 2009, Geochronology of unconformity-related uranium deposits in the Athabasca Basin, Saskatchewan, Canada and their integration in the evolution of the basin: Mineralium Deposita, v. 44, no. 1, p. 41-59.

Allen, D. J., Hinze, W. J., and Cannon, W. F., 1992, Drainage, topographic, and gravity anomalies in the Lake Superior region: Evidence for a 1100 Ma mantle plume: Geophysical Research Letters, v. 19, no. 21, p. 2119-2122.

Allen, P. A., and Allen, J. R., 2013, Basin analysis: Principles and application to petroleum play assessment, John Wiley \& Sons.

Ault, A. K., Flowers, R. M., and Bowring, S. A., 2009, Phanerozoic burial and unroofing history of the western Slave craton and Wopmay orogen from apatite (U-Th)/He thermochronometry: Earth and Planetary Science Letters, v. 284, no. 1-2, p. 1-11.

Behrendt, J. C., Hutchinson, D., Lee, M., Thornber, C., Trehu, A., Cannon, W., and Green, A., 1990, GLIMPCE seismic reflection evidence of deep-crustal and upper-mantle intrusions and magmatic underplating associated with the Midcontinent Rift system of North America: Tectonophysics, v. 173, no. 1-4, p. 595-615.

Bickford, M., Mock, T., Steinhart Iii, W., Collerson, K., and Lewry, J., 2005, Origin of the Archean Sask craton and its extent within the Trans-Hudson orogen: evidence from $\mathrm{Pb}$ and $\mathrm{Nd}$ isotopic compositions of basement rocks and post-orogenic intrusions: Canadian Journal of Earth Sciences, v. 42, no. 4, p. 659-684.

Cawood, P. A., and Hawkesworth, C. J., 2014, Earth's middle age: Geology, v. 42, no. 6, p. 503506.

Cox, K., 1993, Continental magmatic underplating: Philosophical Transactions of the Royal Society of London A: Mathematical, Physical and Engineering Sciences, v. 342, no. 1663, p. 155-166.

Davidson, A., 2008, Late Paleoproterozoic to mid-Neoproterozoic history of northern Laurentia: an overview of central Rodinia: Precambrian Research, v. 160, no. 1, p. 5-22.

Durrheim, R. J., and Mooney, W. D., 1991, Archean and Proterozoic crustal evolution: Evidence from crustal seismology: Geology, v. 19, no. 6, p. 606-609.

Eaton, D. W., and Frederiksen, A., 2007, Seismic evidence for convection-driven motion of the North American plate: Nature, v. 446, no. 7134, p. 428-431.

Eriksson, P. G., Mazumder, R., Catuneanu, O., Bumby, A. J., and Ilondo, B. O., 2006, Precambrian continental freeboard and geological evolution: a time perspective: EarthScience Reviews, v. 79, no. 3, p. 165-204.

Ernst, R., and Bleeker, W., 2010, Large igneous provinces (LIPs), giant dyke swarms, and mantle plumes: significance for breakup events within Canada and adjacent regions from 2.5 Ga to the Present: Canadian Journal of Earth Sciences, v. 47, no. 5, p. 695-739.

Everitt, R., McMurry, J., Brown, A., and Davison, C., 1996, Geology of the Lac Du Bonnet batholith, inside and out: AECL's underground research laboratory, southeastern Manitoba, in Proceedings Field excursion B-5: guidebook. Geological Association of Canada-Mineralogical Association of Canada Joint Annual Meeting. 
Feinstein, S., Kohn, B., Osadetz, K., Everitt, R., and O'Sullivan, P., 2009, Variable Phanerozoic thermal history in the Southern Canadian Shield: Evidence from an apatite fission track profile at the Underground Research Laboratory (URL), Manitoba: Tectonophysics, v. 475, no. 1, p. 190-199.

Flowers, R., Bowring, S., Mahan, K., Williams, M., and Williams, I., 2008, Stabilization and reactivation of cratonic lithosphere from the lower crustal record in the western Canadian shield: Contributions to Mineralogy and Petrology, v. 156, no. 4, p. 529-549.

Flowers, R. M., Bowring, S. A., and Reiners, P. W., 2006a, Low long-term erosion rates and extreme continental stability documented by ancient (U-Th)/He dates: Geology, v. 34, no. 11, p. 925-928.

Flowers, R., Mahan, K., Bowring, S., Williams, M., Pringle, M., and Hodges, K., 2006b, Multistage exhumation and juxtaposition of lower continental crust in the western Canadian Shield: Linking high-resolution U-Pb and 40Ar/39Ar thermochronometry with pressure-temperature-deformation paths: Tectonics, v. 25, no. 4.

Flowers, R. M., Ault, A. K., Kelley, S. A., Zhang, N., and Zhong, S., 2012, Epeirogeny or eustasy? Paleozoic-Mesozoic vertical motion of the North American continental interior from thermochronometry and implications for mantle dynamics: Earth and Planetary Science Letters, v. 317-318, no. 0, p. 436-445.

Forte, A. M., Moucha, R., Simmons, N. A., Grand, S. P., and Mitrovica, J. X., 2010, Deepmantle contributions to the surface dynamics of the North American continent: Tectonophysics, v. 481, p. 3-15.

Frimmel, H. E., 1997, Chlorite thermometry in the Witwatersrand Basin: constraints on the Paleoproterozoic geotherm in the Kaapvaal Craton, South Africa: The Journal of Geology, v. 105, no. 5, p. 601-616.

Furlong, K. P., and Fountain, D. M., 1986, Continental crustal underplating: Thermal considerations and seismic-petrologic consequences: Journal of Geophysical Research: Solid Earth, v. 91, no. B8, p. 8285-8294.

Hoffman, P. F., 1988, United Plates of America, the birth of a craton: Early Proterozoic assembly and growth of Laurentia: Annual Review of Earth and Planetary Sciences, v. 16, p. 543-603.

Hunt, P. A., and Roddick, J. C., 1988, A compilation of K-Ar ages: Report 18; Radiogenic Age and Isotopic Studies: Report 2: Geological Survey of Canada.

Jaupart, C., J. C. Mareschal, H. Bouquerel, and C. Phaneuf, 2014, The building and stabilization of an Archean Craton in the Superior Province, Canada, from a heat flow perspective, Journal of Geophysical Research: Solid Earth.

Jordan, T. H., 1978, Composition and development of the continental tectosphere: Nature, v. 274 , no. 5671 , p. $544-548$.

Karlstrom, K. E., and Timmons, J. M., 2012, Many unconformities make one Great Unconformity: Spec. Pap., Geol. Soc. Am, v. 489, p. 73-79.

Kelly, C.J., Schneider, D.A., Jackson, S.E., Kalbfleisch, T. and McFarlane, C.R., 2017, Insights into low-to moderate-temperature recrystallization of zircon: Unpolished crystal depth profile techniques and geochemical mapping. Chemical Geology, 449, p. 82-98.

Kennedy, A.K., Kamo, S.L., Nasdala, L. and Timms, N.E., 2010, Grenville skarn titanite: potential reference material for SIMS U-Th- $\mathrm{Pb}$ analysis. The Canadian Mineralogist, v. 48(6), p. 1423-1443. 
Kohn, B.P., Gleadow, A.J., Brown, R.W., Gallagher, K., Lorencak, M., Noble, W.P., 2005, Visualizing thermotectonic and denudation histories using apatite fission track thermochronology, in: Reiners, P.W., Ehlers, T.A. (Eds.), Reviews in Mineralogy and Geochemistry. Mineralogical Society of America Geochemical Society, Chantilly, Virginia, pp. 527-565.

Kretz, R., 1994, Petrology of veined gneisses of the Otter complex, southern Grenville Province: Canadian Journal of Earth Sciences, v. 31, no. 5, p. 835-851.

Li, Z.-X., Bogdanova, S., Collins, A., Davidson, A., De Waele, B., Ernst, R., Fitzsimons, I., Fuck, R., Gladkochub, D., and Jacobs, J., 2008, Assembly, configuration, and break-up history of Rodinia: a synthesis: Precambrian research, v. 160, no. 1, p. 179-210.

Lovera, O. M., M. Grove, and T. M. Harrison, 2002, Systematic analysis of K-feldspar 40Ar/39Ar step heating results II: relevance of laboratory argon diffusion properties to nature, Geochimica et Cosmochimica Acta, v. 66 no. 7, p. 1237-1255.

Lovera, O. M., Grove, M., Harrison, T. M., \& Mahon, K. I., 1997, Systematic analysis of Kfeldspar 40Ar39Ar step heating results: I. Significance of activation energy determinations. Geochimica et Cosmochimica Acta, 61(15), 3171-3192.

Lovera, O. M., Richter, F. M., and Harrison, T. M., 1989, The 40Ar/39Ar Thermochronometry for Slowly Cooled Samples Having a Distribution of Diffusion Domain Sizes: Journal of Geophysical Research, v. 94, no. B12, p. 17917-17935.

Lovera, O. M., Richter, F. M., and Harrison, T. M., 1991, Diffusion Domains Determined by 39Ar Released During Step Heating: Journal of Geophysical Research, v. 96, no. B2, p. 2057-2069.

McDannell, K. T., P. K. Zeitler, D. G. Janes, B. D. Idleman, and A. K. Fayon, 2018, Screening apatites for (U-Th)/He thermochronometry via continuous ramped heating: Helium age components and implications for age dispersion: Geochimica et Cosmochimica Acta, v. 223, p. 90-106. doi: 10.1016/j.gca.2017.11.031

McDougall, I., and Harrison, T. M., 1999, Geochronology and Thermochronology by the 40Ar/39Ar Method, Oxford University Press, USA.

Mitrovica, J. X., Beaumont, C., and Jarvis, G. T., 1989, Tilting of continental interiors by the dynamical effects of subduction: Tectonics, v. 8, no. 5, p. 1079-1094.

Musacchio, G., White, D., Asudeh, I., and Thomson, C., 2004, Lithospheric structure and composition of the Archean western Superior Province from seismic refraction/wideangle reflection and gravity modeling: Journal of Geophysical Research: Solid Earth, v. 109 , no. B3.

Nelson, K. (1991) A unified view of craton evolution motivated by recent deep seismic reflection and refraction results. Geophysical Journal International 105, 25-35.

Nicholson, S. W., and Shirey, S. B., 1990, Midcontinent rift volcanism in the Lake Superior region: $\mathrm{Sr}, \mathrm{Nd}$, and $\mathrm{Pb}$ isotopic evidence for a mantle plume origin: Journal of Geophysical Research: Solid Earth, v. 95, no. B7, p. 10851-10868.

Nitescu, B., Cruden, A., and Bailey, R., 2006, Crustal structure and implications for the tectonic evolution of the Archean Western Superior craton from forward and inverse gravity modeling: Tectonics, v. 25 , no. 1.

Ola, O., Frederiksen, A., Bollmann, T., van der Lee, S., Darbyshire, F., Wolin, E., Revenaugh, J., Stein, C., Stein, S., and Wysession, M., 2016, Anisotropic zonation in the lithosphere of Central North America: Influence of a strong cratonic lithosphere on the Mid-Continent Rift: Tectonophysics, v. 683, p. 367-381. 
Percival, J., Sanborn-Barrie, M., Skulski, T., Stott, G., Helmstaedt, H., and White, D., 2006, Tectonic evolution of the western Superior Province from NATMAP and Lithoprobe studies: Canadian Journal of Earth Sciences, v. 43, no. 7, p. 1085-1117.

Percival, J., Skulski, T., Sanborn-Barrie, M., Stott, G., Leclair, A., Corkery, M., and Boily, M., 2012, Geology and tectonic evolution of the Superior Province, Canada: Tectonic Styles in Canada: The Lithoprobe Perspective. Geol Assoc Canada Spec Paper, v. 49, p. 321378.

Percival, J. A., and West, G. F., 1994, The Kapuskasing uplift: a geological and geophysical synthesis. Canadian Journal of Earth Sciences, v. 31(7), p. 1256-1286.

Perry, H. K. C., Eaton, D. W. S., and Forte, A. M., 2002, LITH5.0: a revised crustal model for Canada based on Lithoprobe results: Geophys. Jour. Int., v. 150, p. 285-294.

Pollack, H. N., 1986, Cratonization and thermal evolution of the mantle: Earth and Planetary Science Letters, v. 80, no. 1, p. 175-182.

Rainbird, R. H., Heaman, L. M., and Young, G., 1992, Sampling Laurentia: Detrital zircon geochronology offers evidence for an extensive Neoproterozoic river system originating from the Grenville orogen: Geology, v. 20, no. 4, p. 351-354.

Rainbird, R., Stern, R., Rayner, N., and Jefferson, C., 2007, Age, provenance, and regional correlation of the Athabasca Group, Saskatchewan and Alberta, constrained by igneous and detrital zircon geochronology: Bulletin - Geological Survey of Canada, v. 588, p. 193.

Rogers, J. J., and Santosh, M., 2002, Configuration of Columbia, a Mesoproterozoic supercontinent: Gondwana Research, v. 5, no. 1, p. 5-22.

Rudnick, R. L., and Nyblade, A. A., 1999, The thickness and heat production of Archean lithosphere: constraints from xenolith thermobarometry and surface heat flow: Mantle petrology: Field observations and high pressure experimentation: A tribute to Francis R.(Joe) Boyd, v. 6, p. 3-12.

Schmandt, B., Lin, F. C., and Karlstrom, K. E., 2015, Distinct crustal isostasy trends east and west of the Rocky Mountain Front: Geophysical Research Letters.

Schneider, D., Cope, N., and Holm, D., 2013, Thermochronology of the Mont Laurier terrane, southern Canadian Grenville Province, and its bearing on defining orogenic architecture: Precambrian Research, v. 226, p. 43-58.

Schneider, D. A., Heizler, M. T., Bickford, M. E., Wortman, G. L., Condie, K. C., and Perilli, S., 2007, Timing constraints of orogeny to cratonization: Thermochronology of the Paleoproterozoic Trans-Hudson orogen, Manitoba and Saskatchewan, Canada: Precambrian Research, v. 153, p. 65-95.

Schwartz, E.J. and Buchan, K.L., 1982, Uplift deduced from remnant magnetization: Sudbury area since 1250 Ma ago: Earth and Planetary Science Letters, v. 58, p. 65-74.

Scully, K. R., Canil, D., and Schulze, D. J., 2004, The lithospheric mantle of the Archean Superior Province as imaged by garnet xenocryst geochemistry: Chemical Geology, v. 207, no. 3, p. 189-221.

Shen, W., Ritzwoller, M. H., and Schulte-Pelkum, V., 2013, Crustal and uppermost mantle structure in the central US encompassing the Midcontinent Rift: Journal of Geophysical Research: Solid Earth, v. 118, no. 8, p. 4325-4344.

Stein, C. A., Kley, J., Stein, S., Hindle, D., and Keller, G. R., 2015, North America's Midcontinent Rift: When rift met LIP: Geosphere, v. 11, no. 5, p. 1607-1616. 
Thurner, S., Margolis, R., Levander, A., and Niu, F., 2015, PdS receiver function evidence for crustal scale thrusting, relic subduction, and mafic underplating in the Trans-Hudson Orogen and Yavapai province: Earth and Planetary Science Letters, v. 426, p. 13-22.

Thybo, H., and Artemieva, I. M., 2013, Moho and magmatic underplating in continental lithosphere: Tectonophysics, v. 609, p. 605-619.

Van Lankvelt, A., Schneider, D., Biczok, J., McFarlane, C., and Hattori, K., 2016, Decoding Zircon Geochronology of Igneous and Alteration Events Based on Chemical and Microstructural Features: a Study from the Western Superior Province, Canada: Journal of Petrology, p. egw041.

White, D., Musacchio, G., Helmstaedt, H., Harrap, R., Thurston, P., Van der Velden, A., and Hall, K., 2003, Images of a lower-crustal oceanic slab: Direct evidence for tectonic accretion in the Archean western Superior province: Geology, v. 31, no. 11, p. 997-1000.

Whitmeyer, S. J., and Karlstrom, K. E., 2007, Tectonic model for the Proterozoic growth of North America: Geosphere, v. 3, no. 4, p. 220-259.

Williams. M. L. and Hanmer, S., 2006, Structural and metamorphic processes in the lower crust: evidence from the East Athabasca mylonite triangle, Canada, a deep-crustal isobarically cooled terrane. In Brown, M., and Rushmer, T. (Eds.), Evolution and Differentiation of the Continental Crust, Cambridge University Press. p. 231-267.

Young, G.M., 2013, Precambrian supercontinents, glaciations, atmospheric oxygenation, metazoan evolution and an impact that may have changed the second half of Earth history: Geoscience Frontiers, v. 4, no. 3, p. 247-261.

Zhang, H., Lee, S., Wolin, E., Bollmann, T. A., Revenaugh, J., Wiens, D. A., Frederiksen, A. W., Darbyshire, F. A., Aleqabi, G. I., and Wysession, M. E., 2016, Distinct crustal structure of the North American Midcontinent Rift from P wave receiver functions: Journal of Geophysical Research: Solid Earth, v. 121, no. 11, p. 8136-8153. 